\title{
Thrombocytosis and thrombocytopenia are markers of poor outcome in pediatric patients with community-acquired pneumonia
}

Huiming Sun ( $\nabla$ shm_1985@126.com )

Soochow University Affiliated Children's Hospital

Shuxiang Li

Suzhou hospital affiliated to nanjing medical university

Canhong Zhu

Soochow university affiliated children's hospital

Yongdong Yan

Soochow university affiliated children's hospital

Yuqing Wang

Soochow university affiliated children's hospital

Chuangli Hao

Soochow university affiliated children's hospital

Zhengrong Chen

Soochow university affiliated children's hospital

Wei Ji

Soochow university affiliated children's hospital

\section{Research article}

Keywords: Community-acquired pneumonia; Thrombocytosis; Thrombocytopenia

Posted Date: May 9th, 2019

DOI: https://doi.org/10.21203/rs.2.9536/v1

License: (c) (i) This work is licensed under a Creative Commons Attribution 4.0 International License.

Read Full License 


\section{Abstract}

Abstract Background: This study aimed to investigate the prevalence of thrombocytopenia and thrombocytosis in hospitalized pediatric patients with community-acquired pneumonia (CAP), and determine whether thrombocytopenia and thrombocytosis are associated with patient outcome. Methods: A total of 9,372 consecutive patients, who were 1-168 months old, diagnosed with CAP and admitted in the Children's Hospital of Soochow University, were enrolled in the present retrospective observational study. Their clinical and laboratory data were collected. According to the platelet count on admission, these patients were divided into three groups: thrombocytopenia, normal platelet count, and thrombocytosis groups. The clinical characteristics and etiologic pathogens were compared among these groups. The multivariate logistic regression model was applied to identify risk factors for severe CAP, length of hospitalization $\geq 10$ days and respiratory complications. The correlations between platelet count and clinical features were determined by Spearman's correlation. Results: Thrombocytosis and thrombocytopenia were found in 3,376 (36.0\%) and $43(0.5 \%)$ patients, respectively. Normal platelet count was observed in 5,953 (63.5\%) patients. Thrombocytopenia was an independent risk factor of severe CAP (OR, 6.206; 95\% Cl, 2.209-17.436; $\mathrm{P}=0.001$ ), while thrombocytosis was associated with length of hospitalization of $\geq 10$ days $(\mathrm{OR}, 1.315 ; 95 \% \mathrm{Cl}, 1.177-1.470 ; \mathrm{P}<0.001)$. In addition, thrombocytosis was associated with respiratory complications $(\mathrm{OR}, 1.658 ; 95 \% \mathrm{Cl}, 1.171-2.346 ; \mathrm{P}=0.004)$. Platelet count (median 350.0 [IQR 270.2-447.0] × 109/L) was positively correlated with length of hospitalization (median 7.0 [IQR 6.0-9.0] days) ( $r=0.101, \mathrm{P}<0.001)$, but negatively correlated with age (median 12.0 [IQR 3.0-36.0] months) $(r=-0.401, P<0.001)$ and C-reactive protein (median 2.0 [IQR 0.3-10.7] mg/dl) $(r=$ $-0.191, \mathrm{P}<0.001)$. Conclusion: Thrombocytosis is highly prevalent, while thrombocytopenia has low prevalence in pediatric CAP patients. Both thrombocytosis and thrombocytopenia are associated with clinical outcomes in pediatric CAP patients.

\section{Background}

Platelet plays a fundamental role in the development of thrombosis and hemostasis. Increasing evidences have recognized that platelet is an important component in the immune response to infection [1-3]. In the process of infection and inflammation, thrombocytes may secrete various substances, such as cytokines, pro-coagulants, oxidants and antimicrobial peptides, which are involved in beneficial or harmful activities [4-6]. Therefore, an abnormal platelet count may be a critical biomarker for assessing disease severity.

The impact of thrombocytopenia or thrombocytosis on the outcomes of pediatric patients with community-acquired pneumonia (CAP) has been scarcely studied, although previous studies have confirmed that thrombocytopenia and/or thrombocytosis were associated with mortality in adult CAP patients [7-10]. Thrombocytosis is actually more common in childhood [11]. Two studies on pediatric CAP revealed that thrombocytosis is frequently observed in severe bacterial infections, and that thrombocytosis is associated with more severe and protracted diseases $[12,13]$. However, the sample 
size of these studies was limited. Furthermore, the differences in clinical and etiologic characteristics between patients with thrombocytosis and normal platelet count have not been clarified.

To the best of our knowledge, few large-scale studies have investigated the impact of abnormal plate count on the outcomes of pediatric patients with CAP. The present study evaluates the prevalence of thrombocytopenia and thrombocytosis in pediatric CAP patients, and determines whether thrombocytopenia and thrombocytosis is associated with clinical outcomes.

\section{Methods}

In the present retrospective observational study, consecutively admitted pediatric patients, who were diagnosed with CAP at the Children's Hospital of Soochow University (a tertiary teaching hospital), Suzhou, China, between January 2012 and December 2017, were included.

The inclusion criteria were as follows: (1) patients within 1-168 months old; (2) patients with new-onset pulmonary infiltrate on chest X-ray at admission, which may be accompanied by other signs consistent with pneumonia, such as fever, cough, or auscultatory findings.

The exclusion criteria were as follows: (1) patients who received immunosuppressive therapy; (2) patients with primary hematological disorders (immune thrombocytopenia, leukemia, myelodysplastic syndrome, etc.); (3) patients with active tuberculosis; (4) patients hospitalized within the preceding 21 days; (5) patients who experienced trauma or surgery within the preceding two weeks; (6) patients with chronic gastrointestinal disorders; (7) patients with haemolytic anaemias.

The present study was approved by the Ethics Committee of the Children's Hospital of Soochow University. A signed consent was obtained from the patient's guardian.

\section{Data collection and microbiologic evaluation}

Clinical and laboratory data were collected. The collected variables included the patient's demographical information, basic diseases, clinical signs and symptoms, comorbidity, laboratory and chest X-ray findings. The laboratory results were obtained within six hours after admission. The criteria for the microbiologic diagnosis have been previously described $[14,15]$.

\section{Study definitions}

Thrombocytopenia was defined as a platelet count of $<100,000 / L$, while thrombocytosis was defined as a platelet count of $>400,000 / L$. CAP was defined the appearance of a new pulmonary infiltrate on chest Xray at admission, in combination with fever, cough, or auscultatory findings [16]. Severe CAP was determined when the World Health Organization criteria for severe pneumonia was met [17]. Pleural effusion or empyema and lung abscess were considered as respiratory complications in the present study [16]. Fever was defined as an axillary temperature exceeding $38.0^{\circ} \mathrm{C}$. A diagnosis of tachypnea was made when the respiratory rate was higher than the WHO classification categorized by age: $0-2$ months 
old: $>60$ breaths/min; 2-12 months old: $>50$ breaths/min; $1-5$ years old: $>40$ breaths/min; $>5$ years old: $>20$ breaths/min [16].

The cut-off for length of hospitalization was 10 days, considering the sample size and the percentage of children hospitalized for more or less than 10 days. The overall median length of hospitalization was 7.0 days (range: 3.0-56.0 days; interquartile range [IQR]: 6.0-9.0). The percentage of patients with a length of hospitalization of $\geq 10$ days was $19.34 \%(n=1,813)$.

\section{Statistical analysis}

Statistical analyses were performed using SPSS 21.0 software. Data normality was tested using the Kolmogorov-Smirnov test. Continuous variables with non-normal distribution were expressed as median and IQR $\left(25^{\text {th }}-75^{\text {th }}\right.$ percentile). Non-normally distributed continuous variables were analyzed using the Mann-Whitney U-test or kruskal-Wallis test. Categorical variables were compared using chi-squared test or Fisher's exact test. The correlations between variables were determined by spearman correlation. Variables with a univariate $P$-value $\leq 0.1$ were included in the multivariate logistic regression models. $P<0.05$ was considered statistically significant.

\section{Results}

During the study period, a total of 9,372 consecutive patients were enrolled in the present study. The study flowchart was presented in Figure 1. Thrombocytosis was found in 3,376 (36.0\%) patients, while thrombocytopenia was found in $43(0.5 \%)$ patients. Normal platelet count was observed in $5,953(63.5 \%)$ patients. The patient characteristics are presented in Table 1.

Patients with thrombocytopenia were more likely to have severe CAP $(P=0.009)$, neuromuscular disorders $(P=0.004)$, and lower peripheral leukocyte counts $(P=0.009)$, when compared to patients with normal platelet counts. Patients with thrombocytosis were younger $(P<0.001)$, had longer length of hospitalization $(P<0.001)$, more frequently had a length of hospitalization of $\geq 10$ days $(P<0.001)$, and more commonly had severe CAP $(P<0.001)$, cough $(P=0.024)$, wheezing $(P<0.001)$, and a higher peripheral leukocyte count $(P<0.001)$, while these patients less commonly to had asthma $(P<0.001)$, fever $(P<0.001)$, and lower C-reactive protein $(P<0.001)$.

An etiologic diagnosis was identified in 4,186 (44.7\%) patients (Table 2). There was no significant difference in pathogens between patients with thrombocytopenia and patients with normal platelet count. Parainfluenza virus $(P=0.004)$, respiratory syncytial virus $(P<0.001)$, human bocavirus $(P<0.001)$, and rhinovirus $(P=0.004)$ were more frequently identified in patients with thrombocytosis, when compared to patients with normal platelet counts. Adenovirus $(P<0.001)$ and Mycoplasma pneumoniae $(P<0.001)$ were less frequently identified in patients with thrombocytosis, when compared to patients with normal platelet counts. 
Factors associated with severe CAP, length of hospitalization $\geq 10$ days and respiratory complications were analyzed (Table 3). Age, bronchopulmonary dysplasia, congenital heart disease, neuromuscular disorder, wheezing, fever, gastrointestinal symptoms, tachypnea and C-reactive protein were independent predictors of severe CAP. When platelet count was included as a categorical variable, the association between thrombocytopenia and severe CAP was confirmed (OR, 6.206; 95\% Cl, 2.209-17.436; $P=0.001$ ). Asthma, bronchopulmonary dysplasia, congenital heart disease, neuromuscular disorder, wheezing, fever, gastrointestinal symptoms, tachypnea and C-reactive protein were independent predictors of length of hospitalization $\geq 10$ days. When platelet count was taken as a categorical variable, the association between thrombocytosis and length of hospitalization $\geq 10$ days was observed $(\mathrm{OR}, 1.315 ; 95 \% \mathrm{Cl}, 1.177$ $1.470 ; P<0.001)$. Age, asthma, wheezing, fever and $\mathrm{C}$-reactive protein were independent predictors of respiratory complications. Platelet count, as a categorical variable, was associated with respiratory complication (OR, 1.658; 95\% Cl, 1.171-2.346; $P=0.004)$.

The correlation between platelet count at admission and clinical characteristics and outcomes were analyzed. Platelet count (median 350.0 [IQR 270.2-447.0] $\times 10^{9} / \mathrm{L}$ ) was positively correlated with the length of hospitalization (median 7.0 [IQR 6.0-9.0] days) $(r=0.101, P<0.001)$, but was negatively correlated with age (median 12.0 [IQR 3.0-36.0] months) $(r=-0.401, P<0.001)$ and C-reactive protein (median 2.0 [IQR 0.3-10.7] mg/dl) $(r=-0.191, P<0.001)$.

None of the patients in the present study developed hemorrhagic or thromboembolic complications, 9,357 $(99.8 \%)$ patients recovered after treatment, and $15(0.2 \%)$ patients died of respiratory failure.

\section{Discussion}

The present study evaluated the prevalence of thrombocytopenia and thrombocytosis in hospitalized pediatric patients with CAP, and the contributions of these two to clinical outcomes. These present results revealed that thrombocytopenia occurred in a considerable pediatric population, and that both were correlated with poorer outcome.

Thrombocytosis was identified in approximately one-third of the studied pediatric CAP patients, which is consistent with the previously reported percentage (9-48\%) of thrombocytosis in patients with respiratory tract infections [18-20]. In addition, it was found that platelet count was negatively correlated with age, which could be explained by the fact that bone marrow precursor cells in young children are more sensitive to external stimuli, such as infection and inflammation [11].

The prevalence of thrombocytopenia was merely $0.5 \%$ in the present study, indicating that thrombocytopenia is not common in pediatric patients with CAP. In a previous study, the researchers found that patients with thrombocytopenia tended to be older [8]. However, the exact underlying mechanism remains unclear and warrants further investigation.

Thrombocytosis is associated with multiple pathogens. It was observed that parainfluenza virus, respiratory syncytial virus, human bocavirus and rhinovirus are more frequently identified in patients with 
thrombocytosis, when compared to patients with normal platelet counts. However, it has not been fully elucidated why infection could promote thrombocytosis. Similarly, the incidence of respiratory syncytial virus and rhinovirus was also reported to be greater in the thrombocytosis group, when compared to the normal group, in a previous study [21]. However, contrary to these previous findings, the thrombocytosis caused by parainfluenza virus and human bocavirus infection have not been described at present. The investigators speculate that specific viral agents causing CAP may induce the production of interleukin-6, and lead to thrombocytosis. The increased release of interleukin- 6 was reported during parainfluenza virus and human bocavirus infection in vitro and mice experiments [22, 23]. Interleukin-6 induces and increases expression of hepatic thrombopoietin mRNA and consequential thrombocytosis. Thus, the inflammation-associated platelet production depends on interleukin-6 [24]. Adenovirus and Mycoplasma pneumoniae were less frequently identified in patients with thrombocytosis, when compared to patients with normal platelet counts. This could be partly explained by the fact that adenovirus and Mycoplasma pneumoniae infection predominated in older children who less frequently developed thrombocytosis [25].

In the present study, CAP patients with asthma were associated with a lower incidence of respiratory complication. This finding is consistent with that from previous studies [26]. Furthermore, the severity of CAP is largely correlated to comorbid conditions, such as cardiopulmonary and immune status [16]. In agreement with these previous findings, the investigators also found that the conditions of bronchopulmonary dysplasia, congenital heart disease and neuromuscular disorder were independent predictors of severe CAP in the present study.

Thrombocytopenia in adult severe CAP has already been studied $[9,27,28]$. However, few studies have explored the impact of thrombocytopenia on the severity of CAP in pediatric patients. In the present study, it was demonstrated that thrombocytopenia is an independent predictor of severe CAP in pediatric patients.

These present findings revealed that thrombocytosis was independently associated with length of hospitalization $\geq 10$ days and respiratory complications, which is consistent with two previous studies in adult patients, although the exact mechanism for the association of thrombocytosis with respiratory complication remains unclear $[7,8]$. As expected, it was found that platelet counts at admission were positively correlated with length of hospitalization. In addition, platelet count at admission was negatively correlated with C-reactive protein, indicating that lower platelet count might be associated with a stronger inflammatory response in patients with CAP. This was consistent with a previous study that revealed that sepsis shock patients were more likely to have lower platelet counts [29].

There are several limitations associated with the present study. First, the changes in platelet count were not dynamically monitored, and merely the values on admission were included. According to previous studies, the serial measurements of platelet counts during hospitalization could differentiate between a transient event and sustained derangements in platelet count [30-32]. Second, the present findings derived from a single medical center might not applicable to patients in other areas. Hence, a multi-center 
study is necessary in the future. Third, related cytokines were not concurrently analyzed, which limited our understanding of the underlying mechanism.

\section{Conclusions}

Thrombocytosis is highly prevalent in pediatric CAP patients, while thrombocytopenia less frequently occurs. Parainfluenza virus, respiratory syncytial virus, human bocavirus and rhinovirus are more frequently identified in CAP patients with thrombocytosis. Both thrombocytosis and thrombocytopenia may serve as useful prognostic markers for pediatric CAP.

\section{Abbreviations}

CAP: community-acquired pneumonia

IQR: interquartile ranges

\section{Declarations}

\section{Acknowledgements}

The authors wish to thank the patients for participating in this study.

\section{Funding}

This study was funded by the Livelihood science and technology of Suzhou (Huiming Sun, Grant SYS201640), special support for diagnosis and treatment technology of clinical key diseases in Suzhou (Canhong Zhu, Grant LCZX201809), Science and Technology Projects of Suzhou (Zhengrong Chen, Grant SS201869).

\section{Availability of data and materials}

The data that support the findings of this study are available from the corresponding author upon reasonable request.

\section{Authors' contributions}

HMS and SXL and ZRC and WJ were responsible for the study design, literature search and manuscript drafting. HMS and SXL were responsible for the data collection and statistical analysis. HMS and SXL and WJ were mainly responsible for the data interpretation. $\mathrm{CLH}$ and $\mathrm{YQW}$ and $\mathrm{CHZ}$ were responsible for the study concept and critical revision. All authors contributed to the discussion, writing and reviewing the manuscript and all authors have approved the final manuscript.

\section{Ethics approval and consent to participate}


The study protocols were approved by the Ethics Committee of the Children's Hospital of Soochow University. Written informed consent was obtained from their legal guardians.

Consent for publication

Not applicable.

\section{Competing interests}

The authors declare that there are no conflicts of interest.

\section{Author details}

${ }^{1}$ Department of Respiratory Medicine, Children's Hospital of Soochow University, No. 303, Jingde Road, Suzhou, Jiangsu, China.

${ }^{2}$ Department of Clinical Laboratory, Suzhou Hospital Affiliated to Nanjing Medical University. No. 26, Daoqian Road, Suzhou, Jiangsu, China.

\section{References}

1. Yeaman MR: The role of platelets in antimicrobial host defense. Clinical infectious diseases : an official publication of the Infectious Diseases Society of America 1997, 25(5):951-968; quiz 969-970.

2. Fitzgerald JR, Foster TJ, Cox D: The interaction of bacterial pathogens with platelets. Nat Rev Microbio/ 2006, 4(6):445-457.

3. Elzey BD, Sprague DL, Ratliff TL: The emerging role of platelets in adaptive immunity. Cell Immunol 2005, 238(1):1-9.

4. Yeaman MR, Bayer AS: Antimicrobial peptides versus invasive infections. Curr Top Microbiol Immunol 2006, 306:111-152.

5. Ware J, Corken A, Khetpal R: Platelet function beyond hemostasis and thrombosis. Curr Opin Hematol 2013, 20(5):451-456.

6. Kamath S, Blann AD, Lip GY: Platelet activation: assessment and quantification. Eur Heart J 2001, 22(17):1561-1571.

7. Mirsaeidi M, Peyrani P, Aliberti S, Filardo G, Bordon J, Blasi F, Ramirez JA: Thrombocytopenia and thrombocytosis at time of hospitalization predict mortality in patients with community-acquired pneumonia. Chest 2010, 137(2):416-420.

8. Prina E, Ferrer M, Ranzani OT, Polverino E, Cilloniz C, Moreno E, Mensa J, Montull B, Menendez R, Cosentini $\mathrm{R}$ et al: Thrombocytosis is a marker of poor outcome in community-acquired pneumonia. Chest 2013, 143(3):767-775.

9. Brogly N, Devos P, Boussekey N, Georges H, Chiche A, Leroy O: Impact of thrombocytopenia on outcome of patients admitted to ICU for severe community-acquired pneumonia. J Infect 2007, 
55(2):136-140.

10. Gorelik O, Izhakian S, Barchel D, Almoznino-Sarafian D, Tzur I, Swarka M, Beberashvili I, Feldman L, Cohen N, Shteinshnaider M: Prognostic significance of platelet count changes during hospitalization for community-acquired pneumonia. Platelets 2017, 28(4):380-386.

11. Matsubara K, Fukaya T, Nigami H, Harigaya H, Hirata T, Nozaki H, Baba K: Age-dependent changes in the incidence and etiology of childhood thrombocytosis. Acta Haematol 2004, 111(3):132-137.

12. Wolach $B$, Morag $H$, Drucker $M$, Sadan $N$ : Thrombocytosis after pneumonia with empyema and other bacterial infections in children. The Pediatric infectious disease journal 1990, 9(10):718-721.

13. Dodig S, Raos M, Kovac K, Nogalo B, Benko B, Glojnaric I, Dodig M, Cepelak I: Thrombopoietin and interleukin-6 in children with pneumonia-associated thrombocytosis. Arch Med Res 2005, 36(2):124128.

14. Jiang W, Wu M, Zhou J, Wang Y, Hao C, Ji W, Zhang X, Gu W, Shao X: Etiologic spectrum and occurrence of coinfections in children hospitalized with community-acquired pneumonia. BMC Infect Dis 2017, 17(1):787.

15. Sun H, Chen Z, Yan Y, Huang L, Wang M, Ji W: Epidemiology and clinical profiles of Mycoplasma pneumoniae infection in hospitalized infants younger than one year. Respir Med 2015, 109(6):751757.

16. Bradley JS, Byington CL, Shah SS, Alverson B, Carter ER, Harrison C, Kaplan SL, Mace SE, McCracken $\mathrm{GH}, \mathrm{Jr}$., Moore MR et al: The management of community-acquired pneumonia in infants and children older than 3 months of age: clinical practice guidelines by the Pediatric Infectious Diseases Society and the Infectious Diseases Society of America. Clin Infect Dis 2011, 53(7):e25-76.

17. In: Pocket Book of Hospital Care for Children: Guidelines for the Management of Common Childhood IIInesses. edn. Edited by nd. Geneva; 2013. https://www.ncbi.nlm.nih.gov/pubmed/24006557. Accessed 20 Feb 2019.

18. Vlacha V, Feketea G: Thrombocytosis in pediatric patients is associated with severe lower respiratory tract inflammation. Arch Med Res 2006, 37(6):755-759.

19. Kubota M, Maeda H, Yoshimoto J, Kobayashi K, Usami I, Yamaoka K: Thrombocytosis at an early stage of respiratory tract viral infection. Acta Paediatr 2005, 94(3):364-366.

20. Bilavsky E, Yarden-Bilavsky H, Shouval DS, Fisch N, Garty BZ, Ashkenazi S, Amir J: Respiratory syncytial virus-positive bronchiolitis in hospitalized infants is associated with thrombocytosis. Isr Med Assoc J 2010, 12(1):39-41.

21. Zheng SY, Xiao QY, Xie XH, Deng Y, Ren L, Tian DY, Luo ZX, Luo J, Fu Z, Huang AL et al: Association between secondary thrombocytosis and viral respiratory tract infections in children. Sci Rep 2016, 6:22964.

22. Yoshizumi M, Kimura H, Okayama Y, Nishina A, Noda M, Tsukagoshi H, Kozawa K, Kurabayashi M: Relationships between Cytokine Profiles and Signaling Pathways (IkappaB Kinase and p38 MAPK) in Parainfluenza Virus-Infected Lung Fibroblasts. Front Microbio/ 2010, 1:124. 
23. Lin CY, Chung YH, Shi YF, Tzang BS, Hsu TC: The VP1 unique region of human parvovirus B19 and human bocavirus induce lung injury in naive Balb/c mice. PLoS One 2018, 13(8):e0202667.

24. Kaser A, Brandacher G, Steurer W, Kaser S, Offner FA, Zoller H, Theurl I, Widder W, Molnar C, Ludwiczek $O$ et al: Interleukin-6 stimulates thrombopoiesis through thrombopoietin: role in inflammatory thrombocytosis. Blood 2001, 98(9):2720-2725.

25. Wang JL, Huang LT, Wu KH, Lin HW, Ho MY, Liu HE: Associations of reactive thrombocytosis with clinical characteristics in pediatric diseases. Pediatrics and neonatology 2011, 52(5):261-266.

26. Sellares J, Lopez-Giraldo A, Lucena C, Cilloniz C, Amaro R, Polverino E, Ferrer M, Menendez R, Mensa $\mathrm{J}$, Torres A: Influence of previous use of inhaled corticoids on the development of pleural effusion in community-acquired pneumonia. Am J Respir Crit Care Med 2013, 187(11):1241-1248.

27. Feldman C, Kallenbach JM, Levy H, Reinach SG, Hurwitz MD, Thorburn JR, Koornhof HJ: Communityacquired pneumonia of diverse aetiology: prognostic features in patients admitted to an intensive care unit and a "severity of illness" core. Intensive Care Med 1989, 15(5):302-307.

28. Mandell LA, Wunderink RG, Anzueto A, Bartlett JG, Campbell GD, Dean NC, Dowell SF, File TM, Jr., Musher DM, Niederman MS et al: Infectious Diseases Society of America/American Thoracic Society consensus guidelines on the management of community-acquired pneumonia in adults. Clin Infect Dis 2007, 44 Suppl 2:S27-72.

29. Claushuis TA, van Vught LA, Scicluna BP, Wiewel MA, Klein Klouwenberg PM, Hoogendijk AJ, Ong DS, Cremer OL, Horn J, Franitza M et al: Thrombocytopenia is associated with a dysregulated host response in critically ill sepsis patients. Blood 2016, 127(24):3062-3072.

30. Nijsten MW, ten Duis HJ, Zijlstra JG, Porte RJ, Zwaveling JH, Paling JC, The TH: Blunted rise in platelet count in critically ill patients is associated with worse outcome. Crit Care Med 2000, 28(12):3843-3846.

31. Shteinshnaider M, Barchel D, Almoznino-Sarafian D, Tzur I, Tsatsanashvili N, Swarka M, Cohen N, Gorelik 0: Clinical characteristics and prognostic significance of changes in platelet count in an internal medicine ward. Eur J Intern Med 2014, 25(7):646-651.

32. Akca S, Haji-Michael P, de Mendonca A, Suter P, Levi M, Vincent JL: Time course of platelet counts in critically ill patients. Crit Care Med 2002, 30(4):753-756.

\section{Tables}

Table 1. Clinical characteristics of the study population 


$$
(n=43)
$$

$$
\text { Count }(n=5953) \quad(n=3376)
$$

\section{General characteristics}

Age, median (IQR), months

31.0

19.0

5.0

$<0.001$

\begin{tabular}{lcccr} 
& $(12.0-53.0)$ & $(6.0-45.0)$ & $(2.0-13.0)^{\mathrm{b}}$ & \\
\hline Male, $\mathrm{n}(\%)$ & $28(65.1)$ & $3662(61.5)$ & $2156(63.9)$ & 0.074 \\
\hline Length of hospitalization, median (IQR), & 7.0 & 7.0 & 7.0 & $<0.001$ \\
days & $(6.0-10.0)$ & $(6.0-9.0)$ & $(6.0-9.0)^{\mathrm{b}}$ & \\
\hline Length of hospitalization $\geq 10$ days, $\mathrm{n}$ & $11(25.6)$ & $1030(17.3)$ & $772(22.9)^{\mathrm{b}}$ & $<0.001$
\end{tabular}

(\%)

Antibiotic therapy during the preceding 2

$42(97.7)$

5911 (99.3)

3345 (99.1)

0.160

weeks, n (\%)

Duration of symptoms before admission,

7.0

7.0

6.0

0.424

median (IQR), days

$(5.0-10.0)$

$6(14.0)^{\mathrm{a}}$
$(5.0-12.0)$

$247(4.1)$
$(4.0-13.0)$

$204(6.0)^{\mathrm{b}} \quad<0.001$

\section{Underlying medical conditions}

\begin{tabular}{lcccc} 
Asthma, n (\%) & $1(2.3)$ & $397(6.7)$ & $88(2.6)^{\mathrm{b}}$ & $<0.001$ \\
\hline Bronchopulmonary dysplasia, n (\%) & $0(0.0)$ & $104(1.7)$ & $81(2.4)$ & 0.087 \\
\hline Congenital heart disease, n (\%) & $0(0.0)$ & $111(1.9)$ & $74(2.2)$ & 0.457 \\
\hline Neuromuscular disorder, n (\%) & $3(7.0)^{\mathrm{a}}$ & $43(0.7)$ & $18(0.5)$ & 0.003 \\
\hline Respiratory complication & $1(2.3)$ & $146(2.5)$ & $59(1.7)$ & 0.061 \\
\hline Pleural effusion, n (\%) & $1(2.3)$ & $142(2.4)$ & $59(1.7)$ & 0.094 \\
\hline Pulmonary abscess, n (\%) & $0(0.0)$ & $9(0.2)$ & $0(0.0)$ & 0.070 \\
\hline Clinical symptoms and signs & & & $3311(98.1)^{\mathrm{b}}$ & 0.011 \\
\hline Cough, n (\%) & $40(93.0)$ & $5794(97.3)$ & $1300(38.5)^{\mathrm{b}}<0.001$ \\
\hline Fever, n (\%) & $28(65.1)$ & $2189(36.8)$ & $1639(48.5)^{\mathrm{b}}<0.001$
\end{tabular}




\begin{tabular}{|c|c|c|c|c|}
\hline Tachypnea, n (\%) & 8 (18.6) & $621(10.4)$ & $393(11.6)$ & 0.053 \\
\hline Gastrointestinal symptoms, n (\%) & $2(4.7)$ & $687(11.5)$ & $424(12.6)$ & 0.117 \\
\hline \multicolumn{5}{|l|}{ Laboratory findings } \\
\hline \multirow{2}{*}{$\begin{array}{l}\text { Peripheral leukocyte count, median } \\
\text { (IQR), x } 10^{9} / \mathrm{L}\end{array}$} & 6.6 & 8.3 & 11.2 & $<0.001$ \\
\hline & $(4.8-9.4)^{\mathrm{a}}$ & $(6.2-11.0)$ & $(8.7-14.7)^{\mathrm{b}}$ & \\
\hline \multirow[t]{2}{*}{ C-reactive protein, median (IQR), mg/dl } & 3.8 & 3.0 & 1.0 & $<0.001$ \\
\hline & $(0.6-10.9)$ & $(0.5-11.8)$ & $(0.2-7.0)^{b}$ & \\
\hline
\end{tabular}

$\mathrm{CAP}=$ community-acquired pneumonia

Gastrointestinal symptoms include diarrhea and vomiting

a Differences between the thrombocytopenia and normal platelet count group

${ }^{b}$ Differences between the thrombocytosis and normal platelet count group

Table 2. Etiologic diagnosis of the study population 
Thrombocytopenia

$(\mathrm{n}=43)$
Normal Platelet Count

$(n=5953)$
Thrombocytosis

$$
(n=3376)
$$

\section{Virus, n (\%)}

\begin{tabular}{|c|c|c|c|c|}
\hline Adenovirus & $0(0.0)$ & $57(1.0)$ & $9(0.3)^{b}$ & $<0.001$ \\
\hline Influenza virus & $0(0.0)$ & $65(1.1)$ & $25(0.7)$ & 0.217 \\
\hline Parainfluenza virus & $0(0.0)$ & $223(3.7)$ & $168(5.0)^{b}$ & 0.008 \\
\hline $\begin{array}{l}\text { Respiratory syncytial } \\
\text { virus }\end{array}$ & $4(9.3)$ & $580(9.7)$ & $547(16.2)^{b}$ & $<0.001$ \\
\hline $\begin{array}{l}\text { Human } \\
\text { metapneumovirus }\end{array}$ & $1(2.3)$ & $17(0.3)$ & $13(0.4)$ & 0.085 \\
\hline Human bocavirus & $2(4.7)$ & $324(5.4)$ & $248(7.3)^{b}$ & 0.001 \\
\hline Rhinovirus & $4(9.3)$ & $594(10.0)$ & $402(11.9)^{\mathrm{b}}$ & 0.014 \\
\hline Mycoplasma pneumoniae & $4(9.3)$ & 1032 (17.3) & $425(12.6)^{\mathrm{b}}$ & $<0.001$ \\
\hline Bacteria, n (\%) & $0(0)$ & $70(1.2)$ & $48(1.4)$ & 0.615 \\
\hline $\begin{array}{l}\text { Hemophilus } \\
\text { parainfluenzae }\end{array}$ & 0 & 1 & 0 & \\
\hline Haemophilus influenzae & 0 & 9 & 5 & \\
\hline $\begin{array}{l}\text { Streptococcus } \\
\text { pneumoniae }\end{array}$ & 0 & 42 & 30 & \\
\hline
\end{tabular}

Human staphylococcus

Enterobacter aerogenes $\quad 0$

Staphylococcus

0
1

2

4

2

6
3

0

1

epidermidis

Staphylococcus aureus

0

0

1

1

1
1
3

2 aeruginosa
0

Escherichia coli

0

Enterococcus

Klebsiella pneumoniae

0 3

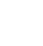

0 
${ }^{b}$ Differences between the thrombocytosis and normal platelet count group

Table 3. Risk factors for severe CAP, length of hospitalization $\geq 10$ days, and respiratory complication

\begin{tabular}{|c|c|c|c|c|c|c|}
\hline \multirow[t]{2}{*}{ Variables } & \multicolumn{2}{|l|}{ Severe CAP } & \multicolumn{2}{|c|}{$\begin{array}{l}\text { Length of hospitalization } \geq \\
10 \text { days }\end{array}$} & \multicolumn{2}{|c|}{ Respiratory complication } \\
\hline & OR $(95 \% \mathrm{CI})$ & $\mathrm{P}$ & OR $(95 \% \mathrm{CI})$ & $\mathrm{P}$ & $\begin{array}{l}\text { OR }(95 \% \\
\text { CI) }\end{array}$ & $\mathrm{P}$ \\
\hline Age & $\begin{array}{l}0.976(0.969- \\
0.984)\end{array}$ & $<0.001$ & $\ldots$ & $\ldots$ & $\begin{array}{l}1.027 \\
(1.023- \\
1.030)\end{array}$ & $<0.001$ \\
\hline Asthma & $\begin{array}{l}0.479(0.215- \\
1.067)\end{array}$ & 0.07 & $\begin{array}{l}0.580(0.435- \\
0.772)\end{array}$ & $<0.001$ & $\begin{array}{l}0.176 \\
(0.054- \\
0.572)\end{array}$ & 0.004 \\
\hline $\begin{array}{l}\text { Bronchopulmonary } \\
\text { dysplasia }\end{array}$ & $\begin{array}{l}3.801(2.453- \\
5.891)\end{array}$ & $<0.001$ & $\begin{array}{l}4.131(3.053- \\
5.590)\end{array}$ & $<0.001$ & $\ldots$ & $\cdots$ \\
\hline $\begin{array}{l}\text { Congenital heart } \\
\text { disease }\end{array}$ & $\begin{array}{l}1.926(1.156- \\
3.208)\end{array}$ & 0.01 & $\begin{array}{l}2.033(1.481- \\
2.789)\end{array}$ & $<0.001$ & $\begin{array}{l}0.162 \\
(0.014- \\
1.953)\end{array}$ & 0.152 \\
\hline $\begin{array}{l}\text { Neuromuscular } \\
\text { disorder }\end{array}$ & $\begin{array}{l}6.773(3.274- \\
14.010)\end{array}$ & $<0.001$ & $\begin{array}{l}2.212(1.290- \\
3.791)\end{array}$ & 0.004 & $\ldots$ & $\ldots$ \\
\hline Wheezing & $\begin{array}{l}1.224(1.057- \\
1.419)\end{array}$ & 0.01 & $\begin{array}{l}1.143(1.036- \\
1.262))\end{array}$ & 0.008 & $\begin{array}{l}0.431 \\
(0.273- \\
0.678)\end{array}$ & $<0.001$ \\
\hline Fever & $\begin{array}{l}0.745(0.588- \\
0.944)\end{array}$ & 0.02 & $\begin{array}{l}0.798(0.711- \\
0.895)\end{array}$ & $<0.001$ & $\begin{array}{l}1.122 \\
(1.014- \\
1.242)\end{array}$ & 0.027 \\
\hline $\begin{array}{l}\text { Gastrointestinal } \\
\text { symptoms }\end{array}$ & $\begin{array}{l}1.718(1.296- \\
2.276)\end{array}$ & $<0.001$ & $\begin{array}{l}1.357(1.159- \\
1.587)\end{array}$ & $<0.001$ & $\ldots$ & $\cdots$ \\
\hline Tachypnea & $\begin{array}{l}10.323(8.359- \\
12.749)\end{array}$ & $<0.001$ & $\begin{array}{l}1.498 \\
(1.281-1.752)\end{array}$ & $<0.001$ & $\begin{array}{l}1.606 \\
(0.955- \\
2.702)\end{array}$ & 0.074 \\
\hline C-reactive protein & $\begin{array}{l}1.008(1.004- \\
1.011)\end{array}$ & $<0.001$ & $\begin{array}{l}1.007(1.004- \\
1.009)\end{array}$ & $<0.001$ & $\begin{array}{l}1.013 \\
(1.010- \\
1.016)\end{array}$ & $<0.001$ \\
\hline \multicolumn{7}{|l|}{ Platelets } \\
\hline Normal range & 1 & Reference & 1 & Reference & 1 & Reference \\
\hline Thrombocytosis & $\begin{array}{l}1.096(0.884- \\
1.358)\end{array}$ & 0.405 & $\begin{array}{l}1.315 \text { (1.177- } \\
1.470)\end{array}$ & $<0.001$ & $\begin{array}{l}1.658 \\
(1.171- \\
2.346)\end{array}$ & 0.004 \\
\hline Thrombocytopenia & $\begin{array}{l}6.206(2.209- \\
17.436)\end{array}$ & 0.001 & $\begin{array}{l}1.681(0.827- \\
3.419)\end{array}$ & 1.151 & $\begin{array}{l}1.093 \\
(0.142- \\
8.390)\end{array}$ & 0.932 \\
\hline
\end{tabular}

$\mathrm{CAP}=$ community-acquired pneumonia

Gastrointestinal symptoms include diarrhea and vomiting

Figures 


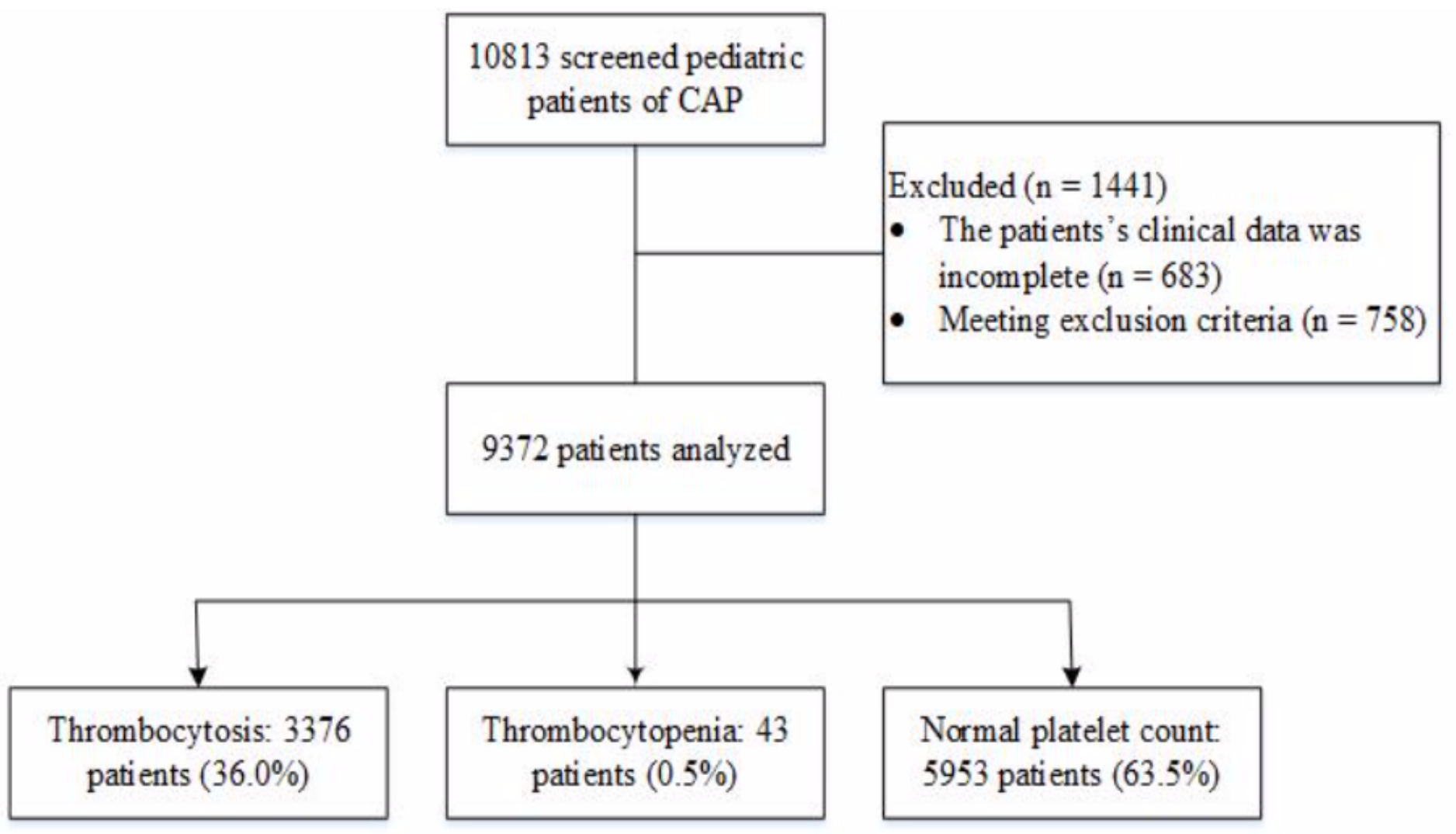

Figure 1

Flowchart of the selected population CAP: community-acquired pneumonia 